\title{
EFFECT OF TEMPERATURE, HUMIDITY AND EXPOSURE TO OXYGEN ON THE SURVIVAL OF ANAEROBIC BACTERIA
}

\author{
S. Hoffmann And T. Justesen \\ Department of Clinical Bacteriology, Institute of Medical Microbiology, University of \\ Copenhagen, Copenhagen, Denmark
}

THE SURVIVAL of anaerobic bacteria during collection, transport and laboratory manipulation of clinical samples is important because the isolation of these bacteria may determine the choice of life-saving antimicrobial treatment. Factors that affect survival include exposure to atmospheric oxygen and light, humidity, temperature, composition of transport media and type of swab, and length of time between collection and culture.

Loesche (1969) introduced the concept of oxygen sensitivity or tolerance and measured the survival of anaerobes on an agar medium exposed to air. Tally et al. (1975) defined oxygen tolerance as the survival time on blood agar in air and Rolfe et al. (1978) expressed oxygen tolerance of bacterial suspensions as the time after inoculation when organisms could not be recovered from suspensions exposed to air at $37^{\circ} \mathrm{C}$. Hagen, Wood and Hashimoto (1976) found a decrease of viability of at least $50 \%$ in Bacteroides fragilis ss. fragilis held for $12 \mathrm{~h}$ at $4^{\circ} \mathrm{C}$ aerobically or anaerobically. Justesen and Nielsen (1976) found a recovery rate of $18-76 \%$ for B. fragilis spp. and $<1.4 \%$ for Peptostreptococcus anaerobius after exposure to air for $24 \mathrm{~h}$ in moist conditions.

The present study was designed to evaluate the relative importance of humidity, temperature, and exposure to oxygen for the survival of anaerobic bacteria of clinical significance.

\section{MATERIALS AND METHODS}

Organisms. Test strains of the following species were used: $B$. fragilis (two strains), $B$. vulgatus, B. thetaiotaomicron, B. melaninogenicus ss. intermedius, Fusobacterium necrophorum, Peptococcus asaccharolyticus (two strains), Peptostreptococcus anaerobius, Eubacterium lentum and Clostridium ramosum. All were isolated from human clinical specimens and identified by the methods of Holdeman, Cato and Moore (1977). They were stored at $-80^{\circ} \mathrm{C}$ in Brain Heart Infusion Broth (Difco). For the survival tests the organisms were grown anaerobically for $18 \mathrm{~h}$ at $35^{\circ} \mathrm{C}$ in Supplemented Brain Heart Infusion Broth (Difco); this culture was diluted tenfold with $T_{2}$ buffer in anaerobic conditions (Meynell and Meynell, 1970) to provide the test suspension.

Incubation conditions. Anaerobic procedures were performed in a glove box with an atmosphere of $\mathrm{N}_{2} 70 \%, \mathrm{H}_{2} 20 \%$ and $\mathrm{CO}_{2} 10 \%$; anaerobic incubation was at $35^{\circ} \mathrm{C}$ in an incubator within the glove box. Aerobic incubation at $35^{\circ} \mathrm{C}$ was in a simple incubator and incubation at $4^{\circ} \mathrm{C}$, anaerobically and aerobically, was in a refrigerator.

Survival tests. One- $\mu$ l volumes of the test suspensions were seeded on sterile membrane filters (Millipore type GSWP, diameter $25 \mathrm{~mm}$, pore size $0.22 \mu \mathrm{m}$; Molsheim, France) under aerobic and anaerobic conditions; the filters were then held under the following conditions. Moist conditions: the membrane filters were applied to the surface of non-nutrient agar plates. Dry conditions: the membrane filters were placed in sterile empty petri dishes. Both moist and dry preparations were held under anaerobic and aerobic conditions, and each set of experiments was made at $4^{\circ} \mathrm{C}$ and $35^{\circ} \mathrm{C}$. Anaerobic conditions: the filters were either held in the anaerobic incubator at $35^{\circ} \mathrm{C}$, or the dishes containing the filters were sealed with oxygen-proof adhesive tape and held at $4^{\circ} \mathrm{C}$. Aerobic conditions: the filters were held in jars containing air supple- 
mented with $10 \% \mathrm{CO}_{2}$ at $4^{\circ} \mathrm{C}$ or $35^{\circ} \mathrm{C}$. The filters seeded under anaerobic conditions had been held in the anaerobic glove box for at least $24 \mathrm{~h}$ before use. Filters were held under each set of conditions for $0 \cdot 375,0.75,1.5,3,6,12,24,48,96,192$ and $384 \mathrm{~h}$. Each strain was examined twice on different occasions.

Recovery of strains. After the appropriate periods one filter from each set of conditions was transferred to supplemented brain heart infusion blood-agar plates inside the glove box and incubated anaerobically at $35^{\circ} \mathrm{C}$ for $48 \mathrm{~h}$.

Controls. For each test strain, a dry filter and a moist filter were seeded anaerobically and aerobically and transferred immediately to nutrient plates.

Evaluation of growth. The density of growth on the filters was compared with the growth on the control filter, which was defined as maximal growth.

\section{RESULTS}

The longest periods after which maximal growth was observed are shown in the table. This will be referred to as the survival periods. Only values from one of the two experiments are shown, because the differences never exceeded one interval on the logarithmic time scale. The survival period was $0 \mathrm{~h}$ if maximal growth was found only on the control filter. The anaerobic conditions always gave survival periods longer than or similar to those found under aerobic conditions. With very few exceptions, the survival period was longer at $4{ }^{\circ} \mathrm{C}$ than at $35^{\circ} \mathrm{C}$. The relative humidity inside the glove box was $50 \%$, while the relative humidity outside the box was $40-50 \%$. For the gram-negative organisms moist conditions gave a longer survival period than the corresponding dry conditions, except with $F$. necrophorum, which showed maximal growth after $6 \mathrm{~h}$ at $4^{\circ} \mathrm{C}$ anaerobically, under moist or dry conditions. For the gram-positive organisms, no constant relationship was found between humidity and survival period. For Pept. anaerobius the survival period was longer under dry conditions than under moist conditions, except for filters held aerobically at $35^{\circ} \mathrm{C}$. For the other gram-positive organisms the survival period under moist conditions was generally longer than or similar to the survival period under dry conditions.

TABLE

Survival of test strains under various conditions of humidity, temperature and oxygen exposure

\begin{tabular}{|c|c|c|c|c|c|c|c|c|}
\hline \multirow{4}{*}{ Organism } & \multicolumn{8}{|c|}{ Survival period (h) under indicated conditions } \\
\hline & \multicolumn{3}{|c|}{ Moist } & & \multicolumn{3}{|c|}{ Dry } & \\
\hline & \multicolumn{2}{|c|}{$4^{\circ} \mathrm{C}$} & \multicolumn{2}{|c|}{$35^{\circ} \mathrm{C}$} & \multicolumn{2}{|c|}{$4^{\circ} \mathrm{C}$} & \multicolumn{2}{|c|}{$35^{\circ} \mathrm{C}$} \\
\hline & AN & $\mathrm{AE}$ & AN & AE & AN & $\mathrm{AE}$ & AN & $\mathrm{AE}$ \\
\hline \multicolumn{9}{|l|}{ Gram-negative organisms } \\
\hline Bacteroides fragilis, strain 1 & 384 & 384 & 48 & 12 & $1 \cdot 5$ & 0.375 & 0 & 0 \\
\hline B. fragilis, strain 3 & 192 & 192 & 48 & 12 & 1.5 & 0 & 0 & 0 \\
\hline B. vulgatus & 384 & 384 & 12 & 3 & 3 & $1 \cdot 5$ & 0.375 & 0 \\
\hline $\begin{array}{l}\text { B. thetaiotaomicron } \\
\text { B. melaninogenicus }\end{array}$ & 384 & 384 & 48 & 12 & $1 \cdot 5$ & 0.375 & $0 \cdot 375$ & 0 \\
\hline ss. intermedius & 12 & 6 & 0.375 & 0 & 0 & 0 & 0 & 0 \\
\hline Fusobacterium necrophorum & 6 & $1 \cdot 5$ & $1 \cdot 5$ & $0 \cdot 375$ & 6 & 0.375 & 0.75 & 0 \\
\hline \multicolumn{9}{|l|}{ Gram-positive organisms } \\
\hline Eubacterium lentum & 96 & 24 & 6 & 3 & 48 & 48 & 6 & 0.375 \\
\hline Clostridium ramosum & 12 & 3 & 6 & 0.75 & 24 & 0.75 & 6 & 0.375 \\
\hline Peptococeus asaccharolyticus & & & & & & & & \\
\hline strain 12 & 96 & 6 & 12 & 1.5 & 6 & 3 & 12 & 1.5 \\
\hline strain 15 & 192 & 6 & 12 & 3 & 192 & 6 & 24 & 1.5 \\
\hline Peptostreptococcus anaerobius & 12 & 6 & 3 & 1.5 & 48 & 12 & 6 & 0.75 \\
\hline
\end{tabular}




\section{DisCUSSION}

In this study, anaerobic bacteria survived for longer periods on membrane filters at $4^{\circ} \mathrm{C}$ than at $35^{\circ} \mathrm{C}$; aerobic samples are generally held at $4^{\circ} \mathrm{C}$ before handling at this laboratory, and $35^{\circ} \mathrm{C}$ was chosen to stimulate bacterial metabolism and, possibly, to enhance the effects of oxygen. Other investigations of the survival of anaerobes (Loesche, 1969; Barry, Fay and Sauer, 1972; Tally et al., 1975; Justesen and Nielsen, 1976) have been performed at unspecified room temperatures that might have varied in the range $18-25^{\circ} \mathrm{C}$.

We did not confirm the deleterious effect of chilling on the survival of anaerobic bacteria reported by Hagen et al. (1976) who found a $50 \%$ decrease in viability of $B$. fragilis ss. fragilis in trypticase soy broth or on trypticase soy agar after $12 \mathrm{~h}$ at $4^{\circ} \mathrm{C}$ under aerobic and anaerobic conditions. Our findings that most strains survived for at least $72 \mathrm{~h}$ under moist conditions at $4^{\circ} \mathrm{C}$ are similar to those of Tally et al. (1975), who found that B. fragilis spp., Peptococcus spp. and Peptostreptococcus spp. survived exposure to room air for at least $72 \mathrm{~h}$. They avoided desiccation by seeding suspensions of bacteria on to blood-agar plates for exposure but this provided the organisms with nutrients. Transport media should not contain nutrients; therefore we placed the filters on pure agar plates and diluted the cultures before seeding to minimise carry-over of nutrients or inhibitors. Loesche (1969) found a $15 \%$ decrease in viability of $B$. fragilis after exposure to room air for $8 \mathrm{~h}$ but he did not continue his observations beyond $8 \mathrm{~h}$ and a viability of $85 \%$ would have been scored as maximal growth in our experiment.

However, our findings contrast with those of Rolfe et al. (1978) who failed to recover strains of Pept. anaerobius, E. lentum, B. melaninogenicus, B. fragilis and B. vulgatus after exposure to air at $37^{\circ} \mathrm{C}$ under moist conditions for much shorter periods than were survived in the present experiments. In this study, anaerobes generally survived for much longer periods under moist conditions than under dry conditions except for P. asaccharolyticus (strain 15) and Pept. anaerobius. Amongst aerobic and facultative species, gram-positive cocci tolerate drying better than gram-negative organisms, and survival of $\beta$-haemolytic streptococci of Lancefield's group A during transport is improved by absorption of specimens on to filter-paper strips (Hollinger et al., 1960) although high temperatures were deleterious. This method provided rapid drying of the samples, similar to the conditions obtained with our dry membrane filters. The fluid was absorbed almost instantaneously by the filter but the dry conditions were detrimental to most bacteria; this finding supports the results of Barry et al. (1972) who emphasised the importance of avoiding desiccation during transport of anaerobic bacteria.

In general, anaerobes survived better under anaerobic than under aerobic conditions. We used air plus $10 \% \mathrm{CO}_{2}$ to remove one variable between aerobic and anaerobic conditions; the resulting $\mathrm{O}_{2}$ concentration of $19 \%$ remains much higher than the limits established for the growth of moderate anaerobes (Loesche, 1969).

The observed survival periods do not necessarily apply to mixtures of two or more species as in clinical samples, in which anaerobes are often found together with aerobic or facultative species. Different abilities to survive during transport may affect the relative recovery of species from mixtures. However, from this study we conclude that the longest survival of anaerobes, when exposed to oxygen, is provided by moist conditions at $4^{\circ} \mathrm{C}$.

\section{SUMMARY}

The relative effect of humidity, temperature and exposure to oxygen on the survival of 11 strains of Bacteroides spp., Fusobacterium necrophorum, Eubacterium lentum, Clostridium ramosum, Peptococcus asaccharolyticus and Peptostreptococcus anaerobius was evaluated. Suspensions of the test strains were applied to membrane filters either in empty sterile petri dishes or on plates of non-nutrient agar to provide dry or moist conditions. The filters were stored aerobically or a naerobically in an atmosphere containing $10 \% \mathrm{CO}_{2}$ at either $4^{\circ} \mathrm{C}$ or $35^{\circ} \mathrm{C}$. After holding periods of $0.375-384 \mathrm{~h}$, the filters were transferred to nutrient plates inside an anaerobic glove box. After incubation the growth on the filters was compared with that on control filters that had not been stored. Survival was better at $4^{\circ} \mathrm{C}$ than at $35^{\circ} \mathrm{C}$. For the gram-negative organisms, survival was better under moist than under dry conditions, whereas for gram-positive organisms this finding was sometimes reversed. The results indicate that, generally, anaerobic bacteria kept under aerobic conditions survive best under moist conditions at $4^{\circ} \mathrm{C}$. 


\section{REFERENCES}

BARRY, A. L., FAY, G. D. AND SAUER, R. L. 1972. Efficiency of a transport medium for the recovery of aerobic and anaerobic bacteria from applicator swabs. Appl. Microbiol., 24, 31.

HaGen, J. C., WoOd, W. S. ANd Hashimoto, T. 1976. Effect of chilling on the survival of Bacteroides fragilis. J. clin. Microbiol., 4, 432.

Holdeman, L. V., Cato, E. P. and Moore, W. E. C. (eds). 1977. Anaerobe laboratory manual, 4th ed. Virginia Polytechnic Institute and State University: Blacksburg, Virginia.

Hollinger, N. F., Lindberg, L. H., Russell, E. L., Sizer, H. B., Cole, R. M., Browne, A. S. AND UPDYKe, E. L. 1960. Transport of streptococci on filter paper strips. Publ. Hlth Rep., Wash., 75, 251.

Justesen, T. AND NieLSEN, M. L. 1976. Survival of anaerobic bacteria during transportation. I. Experimental investigations on the effect of evacuation of atmospheric air by flushing with carbon dioxide and nitrogen. Acta path. microbiol. scand., sect. B, 84, 51 .

LOESCHE, W. J. 1969. Oxygen sensitivity of various anaerobic bacteria. Appl. Microbiol., 18, 723.

Meynell, G. G. AND Meynell, E. 1970. Theory and practice in experimental bacteriology, 2nd ed. Cambridge University Press: Cambridge, p. 25.

Rolfe, R. D., Hentges, D. J., Campbell, B. J. and BarRetT, J. T. 1978. Factors related to the oxygen tolerance of anaerobic bacteria. Appl. environ. Microbiol., 36, 306.

Tally, F. P., Stewart, P. R., Sutter, V. L. and Rosenblatt, J. E. 1975. Oxygen tolerance of fresh clinical anaerobic bacteria. J. clin. Microbiol., 1, 161.

\section{Journal of Medical Microbiology}

\section{Correction to Volume 13, no 4. November 1980}

In the book reviews of "Antibiotic interactions" edited by J. D. Williams (page 613) and "MCQ tutor for students and microbiology" by J. Gordon (page 618), the texts were transposed so that each appeared under the wrong heading. Both reviews will be reprinted in the May issue of the journal. 